\title{
ナノ閉じ込めされた液体潤滑剤の粘弾性特性の周波数依存性*
}

\author{
伊藤 伸太郎*1, 福 澤 健 二*1, *2 \\ 浜 本 祐 也苂, 張 賀 東*4
}

\section{Frequency Dependence of Viscoelasticity of Liquid Lubricant Confined in Nanometer-Scale Gaps}

\author{
Shintaro ITOH $^{* 5}$, Kenji FUKUZAWA, \\ Yuya HAMAMOTO and Hedong ZHANG \\ ${ }^{* 5}$ Department of Micro-Nano Systems Engineering, Nagoya University, \\ Furo-cho, Chikusa-ku, Nagoya-shi, Aichi, 464-8603 Japan
}

\begin{abstract}
When a liquid is confined in nanometer-scale gaps, it exhibits characteristic viscoelastic properties that are different from those properties measured in a bulk state. In hard disk drives, a liquid lubricant film whose thickness is around $1-2 \mathrm{~nm}$ is used to lubricate the interface between the magnetic head and the magnetic disk surface. When the magnetic head touches the disk surface, the lubricant film is confined in the nanometer-scale gaps and sheared. In order to attain the proper lubrication, it is essential to investigate the dynamic viscoelasticity of the confined liquid lubricant under shearing motion. In this study, we focused on one of the typical phenomenon of the confined liquid which is referred to as the shear thinning. The shear thinning is the property whereby the viscosity of the liquid decreases when the shear rate or shear frequency increases. This can be observed in many lubricants in a bulk state. The characteristic behavior of the confined lubricant is that the shear thinning can be observed at much lower shear rates or shear frequencies compared to the shear thinning occurs in a bulk state. The mechanism of the shear thinning in the confined state must be different from that of the bulk state. In order to clarify the shear thinning mechanism of the confined lubricant, we measured the gap dependence of the viscoelasticity at different shear frequencies in a range of $100 \mathrm{~Hz}$ to $2 \mathrm{kHz}$. The experimental results showed that the shear thinning behavior suddenly appeared at gap width of approximately $15 \mathrm{~nm}$ or less. Further, the shear thinning synchronized with the enhancement of the elasticity which means the solidification of the liquid lubricant.
\end{abstract}

Key Words : Nano-Tribology, Nano-Rheology, Viscoelasticity, Shear Thinning, Confined Lubricant

\section{1. 緒諭}

磁気ディスク装置の記録密度の增大には, 磁気ビッ トの微小化とそれに対応した磁気ヘッドと磁気ディス ク間の隙間の狭小化が必須であり，次世代の磁気ディ スク装置では隙間 $3 \mathrm{~nm}$ の実現が必要とされている. そのような状況においては, 磁気ヘッドは磁気ディス クと間欠的もしくは連続的に接触摺動しながら情報の 記録・再生を行わなければならない，磁気ディスク上 には厚さ 1-2 nm の液体潤滑膜が塗布されている. 接触

$*$ 原稿受付 2007 年 8 月 21 日.

*1 正員, 名古屋大学大学院工学研究科 (焉 464-8603 名古屋市 千種区不老町).

*2 正員, (独) 科学技術振興機構さきがけ(区332-0012 川口市 本町 4-1-8)

*3 学生員, 名古屋大学大学院情報科学研究科.

*4 正員, 名古屋大学大学院情報科学研究科.

E-mail : s_itoh@nuem.nagoya-u.ac.jp
摺動する磁気ヘッドと磁気ディスク間の安定的な相対 運動を実現するためには, 液体潤滑膜の摺動時におけ る粘弾性特性の解明が重要な課題となっている. 磁気 ヘッドによる液体潤滑膜の摺動において特徵的な条件 は, 潤滑剤分子がその大きさと同程度のナノメートル オーダの微小隙間に閉じこめられた状態においてせん 断される点である.ここでは, このように潤滑剤が分 子サイズの微小隙間に拘束されている状態をナノ閉じ こめ状態とよぶ. Israelachviliや Granick らは表面力测 定装置(SFA: Surface force apparatus)を用いた摺動実験 により，ナノ閉じこめ状態における液体高分子が，粘 性の增大や shear thinning 挙動の顕在化など, バルク状 態とは異なる特有の粘弾性特性を示すと報告している (1)-4)。ただし SFA を用いた摺動実験においては，摺動 の繰り返し周波数が淮静的〜約 $100 \mathrm{~Hz}$ の低周波数領 域に制限されることや，液体を挟み込む固体表面には 原子レベルで平滑な雲母基板の使用が必要であること 
など,ある特定の条件下での粘弾吽特吽の测定となる. ナノ閉じこめされた夜体の粘弾性特性について, 高周 波数領域での特性を解明し，さらに磁気ディスク基板 のようにより 般的な工業表面での挙動を解明するた めに，著者らはこれまでの䂧究において，先端を球形 状に加工した光ファイバーを摺動子として利用する新 規なせん断力測定法を考案・開発した(5). 本测定法を ファイバーウォブリング法(FWM: Fiber wobbling method) とよぶ. FWM では数 $\mathrm{Hz}$ 数 $\mathrm{kHz}$ までの動的 粘弾性特性が測定可能であり, 摺動する固体基板の性. 状に特定の制限はない，また，せん断力の検出限界は $1 \mathrm{nN}$ 以下を達成している. さらに，摺動子と固体基板 間の隙間を, 数 $\mu \mathrm{m}$ から数 $\mathrm{nm}$ の範网において任意に設 定することが可能であり, 隙間の送り精度は $0.1 \mathrm{~nm}$ 才 一ダの高精度を実現している.

本研究では, ナノ閉じ込め状態の液体高分子に特徵 的な力学特吽のつである shear thinning に着目する. shear thinning とは，せん断速度もしくはせん断の繰り 返し周波数の增加に伴い粘度が低下する現象であり, バルク状態においても潤滑剤の種類によっては, 高せ ん断速度もしくは高周波数領域において観測される場 合がある. ナノ閉じ込め状態において特徵的であるの は, バルク状態では shear thinning が起こらない条件, すなわち潤滑剂の種類や，せん断速度もしくはせん断 周波数においても, shear thinning が観測されることで あり，バルク状態とはそのメカニズムが異なると考え られる，そこで本研究では，ナノ閉じ込め状態にある 潤滑剤の shear thinning 現象のメカニズム解明を目的と し，著者らが開発した FWM を用いて，100 Hz から 2 $\mathrm{kHz}$ の異なる繰り返し周波数において，粘弾性特性の 隙間依存性を测定し，隙間の狭小化が粘弾性特性の周 波数依存性に与える影響の解明を試みた，潤滑剂には 磁気ディスク装置に用いられるフッ素系潤滑剤(Zdol) を使用し，固体基板には DLC 保護膜付きの磁気ディ スク基板を用いた。

\section{2. ファイバーウォブリング法による動的粘弾性测定}

\section{$2 \cdot 1$ ファイバーウォブリング法の原理＼cjkstart著者ら} が開発したファイバーウォブリング法(FWM: Fiber wobbling method)は，摺動隙間を $0.1 \mathrm{~nm}$ オーダの分解 能で制御し，摺動に際してはたらくせん断力を $0.1 \mathrm{nN}$ オーダの感度で測定することが可能である．また，摺 動の繰り返し周波数を数 $\mathrm{Hz}$ 数 $\mathrm{kHz}$ の広带域におい て任意に設定することが可能である．本測定法の概略 を図 1 に示す．本測定法は摺動子として先端を球形状

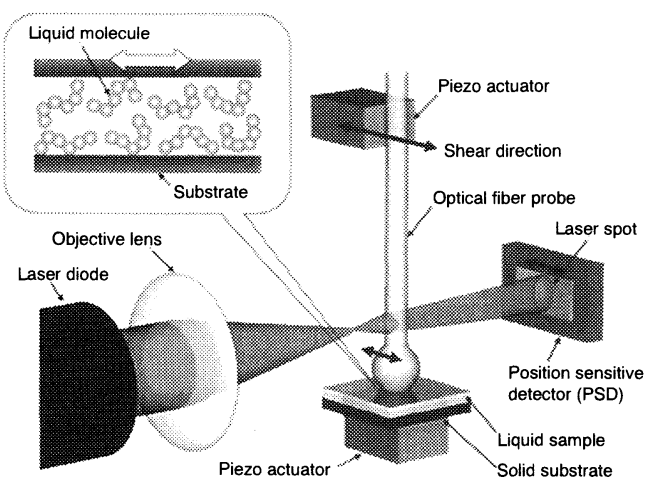

Fig. 1 Schematic diagram of fiber wobbling method.

に加工した光ファイバープローブを用いることを特徵 とする. 基板に対して垂直に配置した光ファイバープ ローブをピエゾアクチュエータにより駆動して，その 先端の球(先端球)により基板上に塗布された液体試料 を摺動する．液体試料は基板表面と先端球表面の隙間 に閉じこめられた状態でせん断される，先端球にはた らくせん断力, すなわち隙間に挟まれた液体の流動・ 変形に必要な力は, プローブのたわみを検出すること により測定する．基板に対して垂直に配置された光フ アイバープローブはせん断方向には柔軟であるが，隙 間方向には剛性が高い，これは高感度なせん断力検出 と精密な隙間制御の両市が可能であることを意味し， 隙間送りにフィードバック駆動のピエゾアクチュエー 夕を用いることにより, $0.1 \mathrm{~nm}$ オーダの隙間制御を可 能としている. 高感度なせん断力測定を実現するには, プローブのたわみを高感度に検出することが必須であ り，著者らはファイバーの円筒部分をマイクロ円筒レ ンズとして用いる独自の変位測定法を開発した ${ }^{(6)(7)}$.こ れは，ファイバーを円筒レンズとして使用し，レーザ ービームを集光して光位置センサ(PSD: Position sensitive detector)上にレーザースポットを形成する．フ アイバーのたわみは, PSD 上のレーザースポットの位 置を検出することにより測定可能となる.この測定法 により，10 pmオーダのたわみ測定を実現した.これ は, 力感度に換算すると $1 \mathrm{nN}$ 以下に相当する. 光ファ イバープローブの円筒部分の直径は約 $100 \mu \mathrm{m}$, 先端球 の直径は約 $200 \mu \mathrm{m}$, 長さは 2-3 mm である. このプロ 一ブの大きさは表面力測定装置のプローブに比べると

桁〜二桁小さく, 共振周波数か数 $\mathrm{kHz}$ 以上となるた め, 摺動実験における繰り返し周波数を数 $\mathrm{kHz}$ の高周 波数まで設定することができる.

$2 \cdot 2$ 功的粘弾性特性の測定法 ファイバーウォ ブリング法を用いて動的粘弾性特吽を测定するには, 
光ファイバープローブの固定端を止弦的に加振し, 先 端球が試料を接触摺動している場合と，接触していな い場合について，それぞれプローブの先端の振動振幅 および位相を測定する. 両者間の振幅比 $\kappa$ と位相遅れ $\delta$ を用いて, 次に示す式(1)および式(2)により動的粘性 倸数 $\eta^{\prime}$ と動的弾性俰数 $\eta^{\prime \prime}$ を算出する. 式(1), 式(2)の 導出については参考文献(5)の第 2 章を参照されたい.

$$
\begin{aligned}
& \eta^{\prime}=\frac{\left(k-m \omega^{2}\right) \sin \delta}{\kappa \omega \Omega} \\
& \eta^{\prime \prime}=\frac{\left(k-m \omega^{2}\right)(\cos \delta-\kappa)}{\kappa \omega \Omega}
\end{aligned}
$$

ここで， $\omega, k, m$ および $\Omega$ はそれぞれ，加振周波 数, プローブのばね定数, 先端球の質量および摺重面 の形状から決まる幾何パラメータである. 本実験系の ように, 隙間 $h$ を介して直径 $d$ の球と平板が平行に相 対運動する場合には， $\Omega$ は解析的に求められており, 次式で表される(8).

$$
\Omega=3 \pi d\left[\left(\frac{8}{15}\right) \log \left(\frac{d}{h}\right)+\cdots\right] \approx\left(\frac{8}{5}\right) \pi d \log \left(\frac{d}{h}\right)
$$

ここで右辺の近似式は， $h<d$ の時に成立する.

先端球と基板との相対的な距離は，隙間送りに使用 するピエゾアクチュエータの送り量から知ることがで きるが，隙間 $h$ は摺動実験において直接測定すること はできない，そのため, 先端球と固体基板との固体接 触の開始点を同定し, その点を基準とすることにより, ピエゾアクチュエータの送り量から, 先端球と基板と の絶対的な隙間を同定する. 固体接触の開始点はプロ 一ブの振動振幅の変化率を算出し, 固体接触による急 激な振幅の減少を検出することにより同定することが 可能である(5). ただし，第 $3 \cdot 1$ 節ならびに第 $3 \cdot 2$ 節 に述べるように, プローブの先端球と固体基板として 用いる磁気ディスクの表面は, 分子レベルで平滑に仕 上げられているものの, ナノメートルオーダの精度で 隙間 $h$ を決めるにはそれらの表面粗さを考慮する必要 がある. すなわち, 表面粗さが存在するために, 先端 球と磁気ディスクの間で固体接触が生じている場合に おいても, 粗さに相当する隙間が存在し, 隙間がゼロ となる点や隙間の絶対值を単純に決めることができな
い.ここでは, 隙間 $h$ として, 微小隙間におけるせん 断流れにおいて通常使用されている表面粗さの中心線 間の距離, すなわち平均隙間 $h_{a v e}$ を用いることとする.

般に粗さの突起分布がガウス分布に従う場合, かつ 見かけの接触域の代表的な長さが，粗さの代表的な波 長と比較して十分大きい場合には, 固体接触は確率的 に平均隙間が $3 \mathrm{R}_{\mathrm{rms}}$ のときに発生する ${ }^{(9)}$. ここで, $\mathrm{R}_{\mathrm{rms}}$ は先端球と基板の複合表面粗さを意味し, 次式により 定義される.

$$
\mathrm{R}_{\mathrm{rms}}=\sqrt{\mathbf{R}_{\mathrm{brms}}^{2}+\mathrm{R}_{\mathrm{drms}}^{2}}
$$

$\mathrm{R}_{\mathrm{brms}}$ および $\mathrm{R}_{\mathrm{drms}}$ はそれぞれ先端球および基板の平 均二乗粗さを表す。これまでの研究において, 先端球 表面および基板として使用する磁気ディスク表面の粗 さの突起分布はガウス分布に近いことが実験的に確認 されている. また先端球と磁気ディスクとの接触域を 円形と仗定し, その直径が接触域の代表的な長さとす ると，付録に示した式(A1)より，本実験系における接 触域の代表的な長さは約 $1 \mu \mathrm{m}$ と見積もられる。第 3 ・ 1 節および第 $3 \cdot 2$ 節において後述するように, 先端球 表面および磁気ディスク表面の平均二乗粗さは，原子 間力顕微鏡(AFM: Atomic force microscopy)を用いて, 位 置の異なる十䇢所において測定した，その際，走査範 网は $1 \mu \mathrm{m}$ とした. 测定の結果, 十箅所で測定した粗 さの平均值は, $\mathrm{R}_{\mathrm{brms}}=0.26 \mathrm{~nm}, \mathrm{R}_{\mathrm{dmms}}=0.42 \mathrm{~nm}$ であつ た. またそれら測定値のばらつきは，先端球は \pm 0.03 $\mathrm{nm}$, 磁気ディスクは $\pm 0.02 \mathrm{~nm}$ となった. 異なる十箇 所で測定した表面粗さのばらつきが, その平均値に比 ベ・桁程度小さいことから，1 $\mu \mathrm{m}$ という走査範井は, 先端球およひ磁気ディスクの表面粗さの代表的な波長 に比べ十分に大きいと考えられる.このことから，接 触域の代表長さとして見積もった約 $1 \mu \mathrm{m}$ という長さ は, 粗さの代表的な波長と比較して十分に大きいと考 えられる. 以上から, 本研究においては, 固体接触が 発生したときの平均隙間を $h_{a v e}=3 \mathrm{R}_{\mathrm{rms}}$ とし, 潤滑剤を 摺動している際の平均隙間 $h_{a v e}$ は以下の手順により実 験的に同定した. まず，摺動実験においてプローブの 振動振幅の変化率を算出し, 固体接触の開始点を同定 する，つぎに，固体接触開始点における平均隙間を $h_{a v e}=3 \mathrm{R}_{\mathrm{rms}}$ とし, 固体接触に至るまでのピエゾアクチ ユエータの隙間送り量に $3 \mathrm{R}_{\mathrm{rms}}$ を加算したものを平均 隙間 $h_{\text {are }}$ とする. 第 $3 \cdot 2$ 節において述べるように, 本 実験系においては $\mathrm{R}_{\mathrm{ms}}=0.49 \mathrm{~nm}$ であった. 


\section{3. 測定装置と実筝手順}

$3 \cdot 1$ 測定装置の檴成 測定装置の構成を図 2 に 示す.プローブ駆動用のピエゾアクチュエータ(Piezo X)により, プローブを基板に対して面内方向に振動さ せる．またステージ駆動用のピエゾアクチュエータ (Piezo Z)によってプローブ先端球と基板表面との隙間 を, $0.1 \mathrm{~nm}$ の分解能で調整する. PSDから得られるプ ローブの変位信号は, 信号処理回路において電流一電 生変換したあと, Piezo X の加振信号を参照信号として ロックインアンプにより同期検波する.ロックインア ンプで得られた振動振幅と位相は, コンピュータに記 録される. 本吥究で用いた光ファイバープローブのサ イズは, 長さ $2.17 \mathrm{~mm}$, ファイバー部の直径 $127 \mu \mathrm{m}$, 先端球の直径 $189 \mu \mathrm{m}$ であった. ばね定数は $96.1 \mathrm{~N} / \mathrm{m}$ であり，共振周波数は $16.9 \mathrm{kHz}$ であった。潤滑剤を摺 動する先端球の表面粗さを AFM を用いて, 位置の異

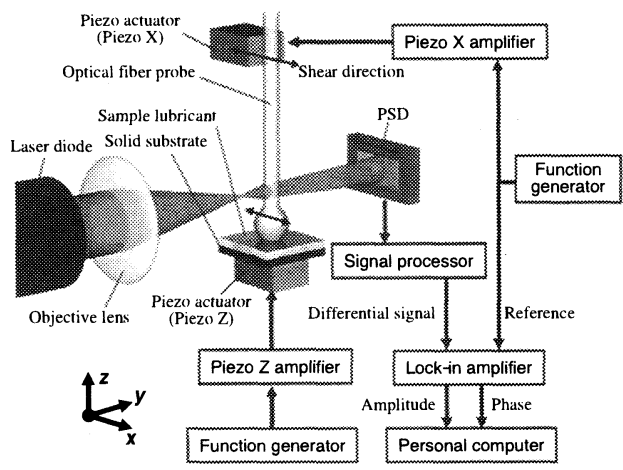

Fig. 2 Block diagram of the experimental apparatus.

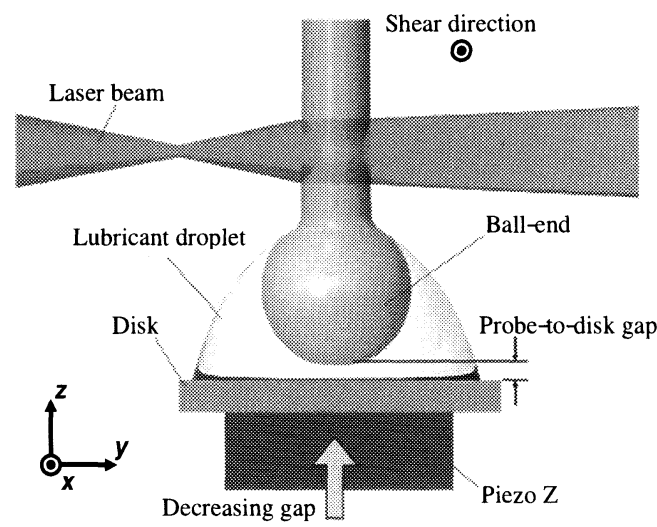

Fig. 3 Experimental procedure for measuring the gap dependence of lubricant viscoelasticity. The size of the lubricant was adjusted to just immerse the ball-end completely.
なる十箇所において測定した. 走査範囲は $1 \mu \mathrm{m}$ とし た. 測定の結果, 算術平均粗さ, 平均二乗粗さ, 最大 粗さの平均值はそれぞれ, $0.22 \mathrm{~nm}, 0.26 \mathrm{~nm}, 1.1 \mathrm{~nm}$ であった.

$3 \cdot 2$ 供試ディスクと供試泪滑剤 基板としては DLC 保護膜付の 2.5 インチ磁気ディスクを使用した. ディスクの表面粗さを先端球と同様に，位置の異なる 十箇所において测定した. 测定の結果, 算術平均粗さ, 二乗平均粗さ, 最大粗さの平均值はそれぞれ $0.33 \mathrm{~nm}$, $0.42 \mathrm{~nm}, 2.0 \mathrm{~nm}$ であった. したがって, ディスクと先 端球により構成される摺動面の複合表面粗さは, $R_{\mathrm{rms}}=0.49 \mathrm{~nm}$ であった. 潤滑剂としてはフッ素系潤滑 剂 Fomblin Zdol(分子量 $4000 \mathrm{amu}$ )を用いた．この潤滑 剂は長さ約 $14 \mathrm{~nm}$ の直鎖状の主鎖構造をもち，末端に 極性の水酸基を有する. 主鎖構造が宂い屈曲性を有し ているため, Zdol 分子は通常ランダムコイル形状をと り,その直径は約 $3 \mathrm{~nm}$ であることが知られている(10).

フッ素化合物である主鎖部分に比べ，末端の水酸基は DLC 表面に対する吸着性が高く, Zdol 分子の 部は, 基板に化学的に吸着することが知られている. また, Ma らは薄膜状態の Zdol の表面流動を测定した結果か ら, 固体表面近傍における Zdol 分子は, 末端の水酸基 の効果により，二〜三分子膜厚にわたって分子層構造 を形成すると報告している(10).

$3 \cdot 3$ 実検手順 周波数依存性を测定するために, 加振周波数を $100 \mathrm{~Hz}, 500 \mathrm{~Hz}, 1 \mathrm{kHz}, 1.5 \mathrm{kHz}, 2 \mathrm{kHz}$ とし, それぞれについて粘弾性特性の隙間依存性を測定した. 加振振幅はすべての実験において約 $25 \mathrm{~nm}$ とした. 粘 弾吽特吽の隙間依存性を測定するための実験手順を以 下に述べる(図 3). シリンジを用いて, 先端球が完全に 浸る程度の量の潤滑剤をディスク上に滴下した.プロ 一ブ先端球を潤滑剂の液滴に浸し，プローブ加振用ピ エゾアクチュエータ (Piezo X)を用いて, プローブを上 に述べた加振周波数および加振振幅にて止弦的に加振 した. 同時に, 隙間制御用ピエゾアクチュエータ(Piezo Z)を用いてプローブ先端球とディスク表面との隙間を 狭小化し，プローブとディスクが固体接触を開始する まで，プローブ先端の振幅と位相を测定した．测定し た振幅および位相から, 式(1), (2)を用いて, 動的粘性. 係数 $\eta^{\prime}$ と動的弾性係数 $\eta^{\prime \prime}$ を算出した. プローブとデ イスク間の平均隙間 $h_{a v e}$ は, 第 $2 \cdot 2$ 節において述べた 方法により同定した.

\section{4. 結果と考察}

各周波数において测定した, 振幅比 $\kappa$ および位相遅 れ $\delta$ を図 4 から図 8 に示す. 図 4 図 8 の横軸は, 先 
端球と磁気ディスクとの平均隙間を表しており，第 $2 \cdot 2$ 節で述べた方法により同定した. 平均隙間の減少 に伴って，位相遅れは緩やかに增大し，振幅は隙間約 $15 \mathrm{~nm}$ 以下から徐々に減少した。 これは後に述べるよ うに，ナノ閉じ込めによる粘性係数および弾性係数の 增大を意味している．また，周波数を高くすると特徵 的であるのは, 位相遅れの增大が平均隙間 $15 \mathrm{~nm}$ 付近 において，屈曲点を示す点である.これは，後に考察 するように，ナノ閉じ込めに起因する shear thinning 挙 動が現れたためと考えられる. 固体接触が起こった後 は, 固体表面同士の直接接触により先端球にはたらく 摩擦力が急增するため, 振幅は急激に隇少する。・方, 位相遅れはわずかに上昇した後に急激に隇少する。こ れは，隙間に介在する潤滑剤が，隙間の狭小化に伴っ て排出され，固体表面同士の接触摺動が支配的となっ

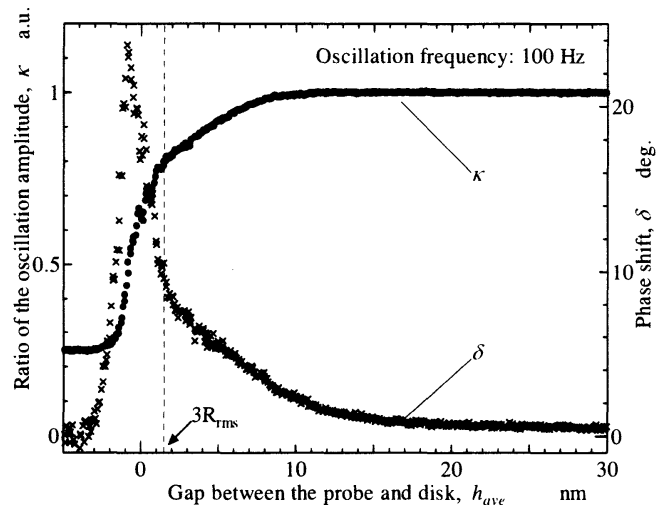

Fig. 4 Ratio of the oscillation amplitude $\kappa$ and the phase shift $\delta$ measured with the oscillation frequency of $100 \mathrm{~Hz}$. The filled circles represent $\kappa$ and the crosses represent $\delta$.

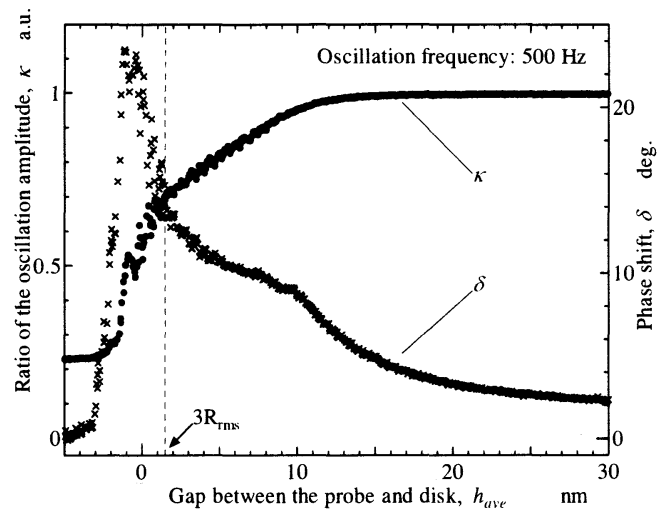

Fig. 5 Ratio of the oscillation amplitude $\kappa$ and the phase shift $\delta$ measured with the oscillation frequency of $500 \mathrm{~Hz}$. The filled circles represent $\kappa$ and the crosses represent $\delta$.

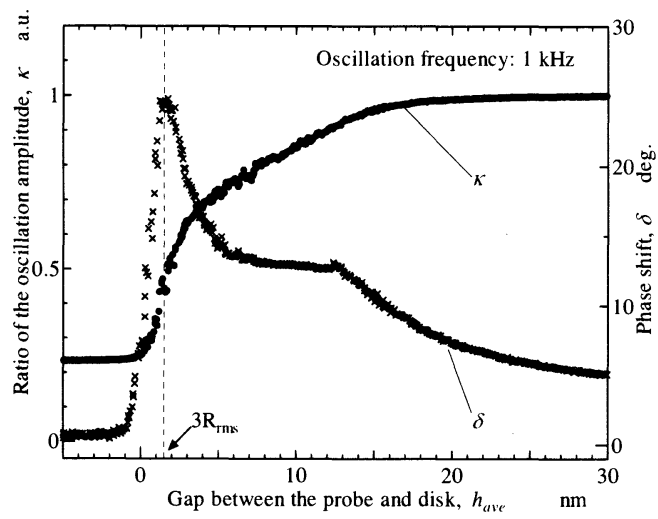

Fig. 6 Ratio of the oscillation amplitude $\kappa$ and the phase shift $\delta$ measured with the oscillation frequency of $1 \mathrm{kHz}$. The filled circles represent $\kappa$ and the crosses represent $\delta$.

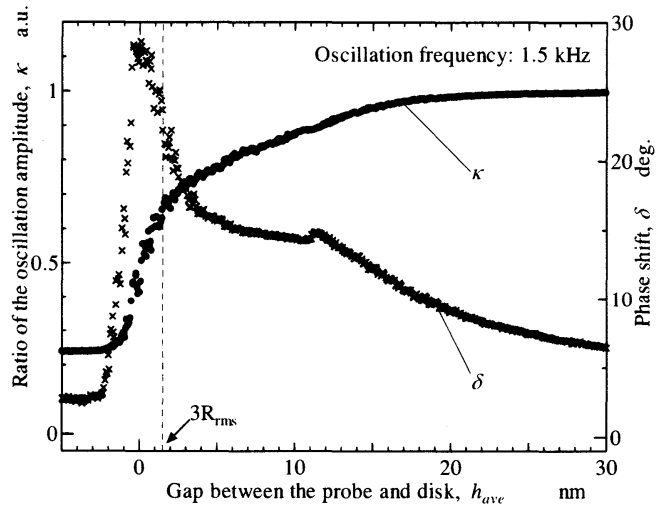

Fig. 7 Ratio of the oscillation amplitude $\kappa$ and the phase shift $\delta$ measured with the oscillation frequency of $1.5 \mathrm{kHz}$. The filled circles represent $\kappa$ and the crosses represent $\delta$.

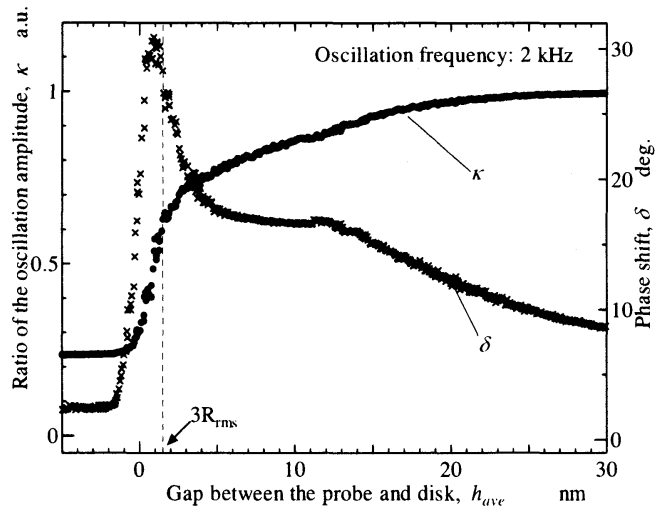

Fig. 8 Ratio of the oscillation amplitude $\kappa$ and the phase shift $\delta$ measured with the oscillation frequency of $2 \mathrm{kHz}$. The filled circles represent $\kappa$ and the crosses represent $\delta$. 


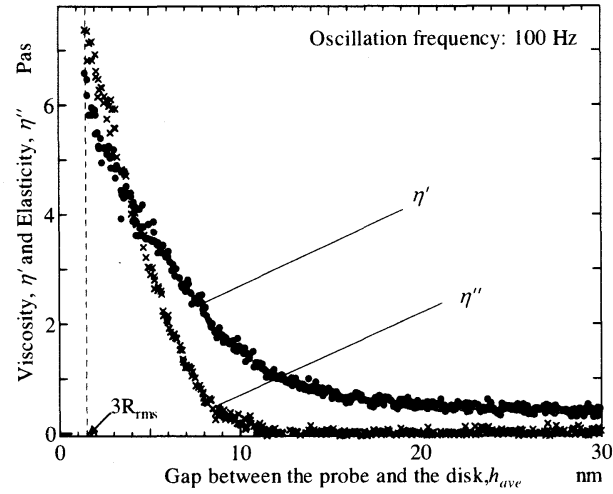

Fig. 9 Gap dependence of the viscosity and the elasticity measured with the oscillation frequency of $100 \mathrm{~Hz}$. The filled circles represent the viscosity and the crosses represent the elasticity.

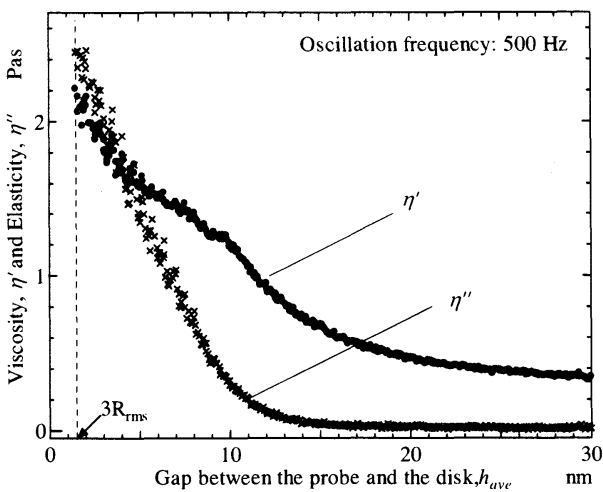

Fig. 10 Gap dependence of the viscosity and the elasticity measured with the oscillation frequency of $500 \mathrm{~Hz}$. The filled circles represent the viscosity and the crosses represent the elasticity.

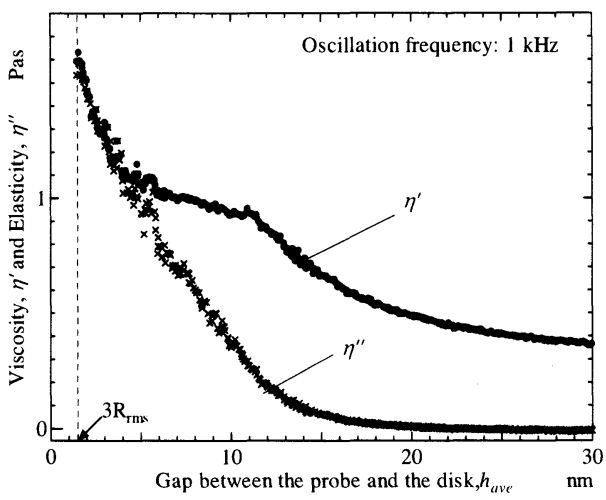

Fig. 11 Gap dependence of the viscosity and the elasticity measured with the oscillation frequency of $1 \mathrm{kHz}$. The filled circles represent the viscosity and the crosses represent the elasticity.

たために，位相に影響する減衰の効果が小さくなった ことが原因と考えられる. 次に, 図 4〜図 8 の測定結 果を，式(1)および式(2)に代入し，隙間 $30 \mathrm{~nm}$ から

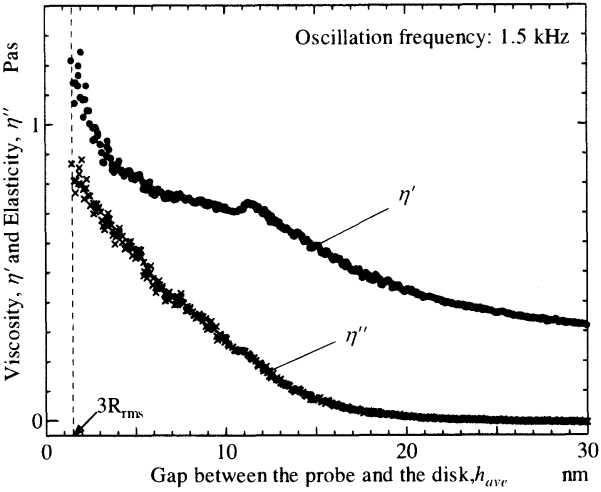

Fig. 12 Gap dependence of the viscosity and the elasticity measured with the oscillation frequency of $1.5 \mathrm{kHz}$. The filled circles represent the viscosity and the crosses represent the elasticity.

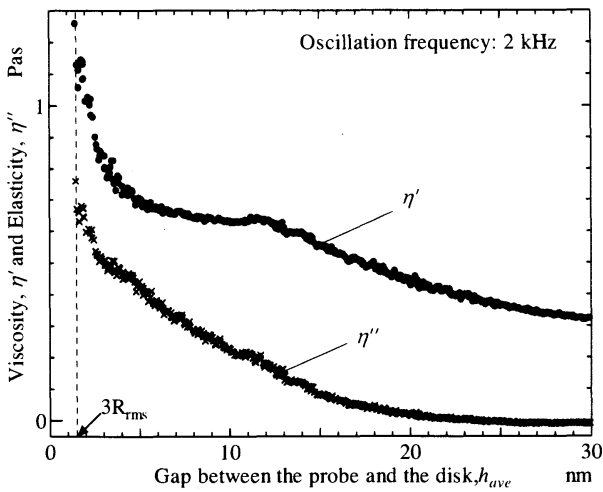

Fig. 13 Gap dependence of the viscosity and the elasticity measured with the oscillation frequency of $2 \mathrm{kHz}$. The filled circles represent the viscosity and the crosses represent the elasticity.

$3 \mathrm{R}_{\mathrm{rms}}(1.47 \mathrm{~nm})$ までの動的粘性係数 $\eta^{\prime}$ と動的弾性俰数 $\eta^{\prime \prime}$ を算出した. 結果を図 9 から図 13 に示す. バルク 状態の Zdol は, 摺動隙間の変化に対しては·定の粘性 係数を示し，弾性係数は無視できる程度に小さく，二 ュートン流体の性質を示す ${ }^{(5)}$. しかしナノメートルオ 一ダの隙間においては, 図9～図 13に示すように, 隙 間の狭小化とともに粘性倸数は增大した．また，バル ク状態ではほぼゼロである弾性係数が，約 $15 \mathrm{~nm}$ 以下 の隙間領域において発現し，隙間の狭小化とともに增 大した．粘性係数の隙間依存性について，加振周波数 による違いを比較すると，最も顕著であるのが，加振 周波数 $100 \mathrm{~Hz}$ では隙間の狭小化に対して, 粘性.係数は ほぼ単調に增加するのに対して，それ以上の加振周波 数においては, $10 \mathrm{~nm} \sim 15 \mathrm{~nm}$ の隙間領域において粘性. 係数の增加傾向に屈曲点が存在することである. 弾性. 係数についてはこのような顕著な差は見られず，どの 周波数においても隙間の狭小化において単調に增加し 
た．粘性係数の加振周波数に対する依存性を定量的に 比較するために，代表的な隙間において，周波数と粘 性係数の関係を両対数グラフにプロットしたものを図 14 に示す. 図 14 から分かるように, 隙間の狭小化と ともに，粘性係数の周波数に対する依存性は顕著とな り, 加振周波数の增加に伴ってほぼ直線的, すなわち 指数関数的に減少した. これはナノ閉じ込め状態に特 有の shear thinning 挙動を示している. 隙間の狭小化に 対する周波数依存性の変化を定量的に比較するために, 粘性係数が指数関数的に隇少することに着目して, 以 下の式(5)を図 14 の測定データに最小二乗法を用いて フィッティングした.

$$
\log \eta^{\prime}=-\alpha \log f+\beta
$$

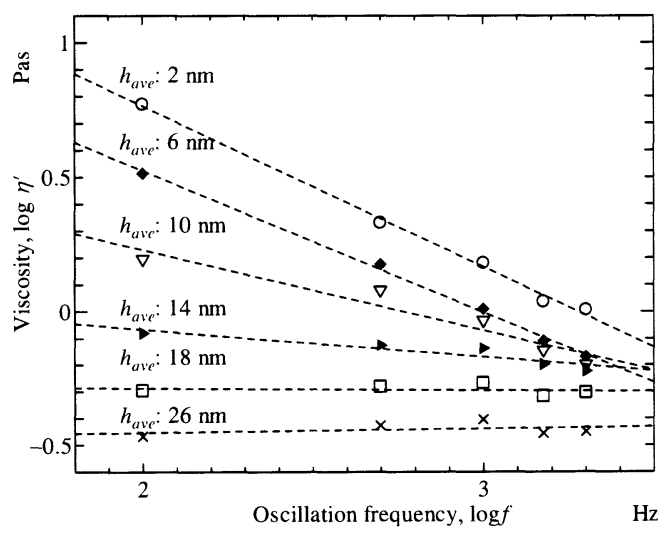

Fig. 14 Relationship between the viscosity and the oscillation frequency at representative gaps in the range of $2 \mathrm{~nm}$ to $26 \mathrm{~nm}$. The data is plotted on a logarithmic graph. The broken line represents the fitting line of equation (5).

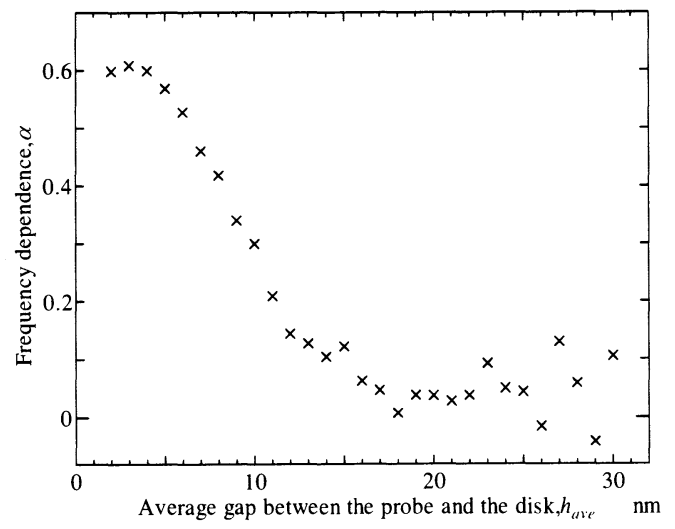

Fig. 15 Relationship between the average gap and frequency dependence of the viscosity, $\alpha$.
図 14 中, 破線で示した直線はフィッティング結果を示 している. 式(5)において直線の傾きを表す $\alpha$ を粘性係 数の周波数依存性を評価するパラメータとして用いる. $\alpha$ が大きいほど, 周波数依存性が大きく, shear thinning による粘性係数の減少がより顕著であることを意味す る. $30 \mathrm{~nm}$ から $2 \mathrm{~nm}$ までの隙間領域において, 隙間 1 $\mathrm{nm}$ 毎の粘性俰数について $\alpha$ を算出した. 結果を図 15 に示す. 図 15 から， $\alpha$ は隙間 $15 \mathrm{~nm}$ 以上ではほぼゼ 口であるが, 隙間が $15 \mathrm{~nm}$ を下回ると, 隙間の狭小化 とともに急激に上昇した．このことから，本測定系に おいて, ナノ閉じ込め状態に特有の shear thinning は, 隙間 $15 \mathrm{~nm}$ 以上では起こらず，隙間が $15 \mathrm{~nm}$ を下回る 領域から顕在化し，隙間の狭小化とともにその影響が 大きくなることが明らかとなった. shear thinning が顕 在化する隙間之, 図 10 から図 13 において, 粘性俰数 の增加傾向が屈曲点を示す隙間領域がおおよそ 致す ることから,この增加傾向の変化は, 隙間 $15 \mathrm{~nm}$ 付近 から突如顕在化する shear thinning に起因すると考えら れる. すなわち, 隙間 $15 \mathrm{~nm}$ 以上では，ナノ閉じ込め の効果のみがはたらき, 隙間の狭小化に伴って粘性係 数は単調に增加するが，隙間が $15 \mathrm{~nm}$ を下回ると, ナ ノ閉じ込めの効果と同時に粘性係数を減少させる効果 として shear thinning がはたらくため, 粘性係数の增大 が鈍化し，結果として隙間の狭小化に対する粘性係数 の增加傾向が屈曲点を示したと考えられる. 加振周波 数が大きくなるにつれて屈曲点が明確に現れるのは, 加振周波数が大きいほど shear thinning による粘性係数 の減少の効果が大きいためと考えられる.

次に, shear thinning が顕在化する隙間約 $15 \mathrm{~nm}$ は, 図9から図13において弾性係数が発現する隙間領域に もほぼ 致することに注目されたい。バルク状態では 観测されず,ナノ閉じ込めに特有の弾性係数の発現は, 閉じ込めの効果により分子運動の遅化した潤滑剂分子 同士が局所的に集合構造を形成することによって，本 来, 液体の性質しかもたない潤滑剂が固体的な性質を もつに至ったためと考えられる と shear thinning の顕在化がほぼ同じ隙間領域から始ま ったことから，この両者に相関があると考えられる.

代表的な隙間における弾性係数と加振周波数との関係 を両対数グラフにプロットしたものを図 16 に示す.図 16 から, 各隙間において加振周波数の增加とともに弾 性係数は減少し, 隙間が小さいほど大幅に減少するこ とが明らかとなった. この弾性係数の減少は, ナノ閉 じ込めの効果により形成された潤滑剂分子の集合構造 が, 加振周波数の增加に伴って破塤されたためと解釈 することができる.これらの結果から推定される, ナ 


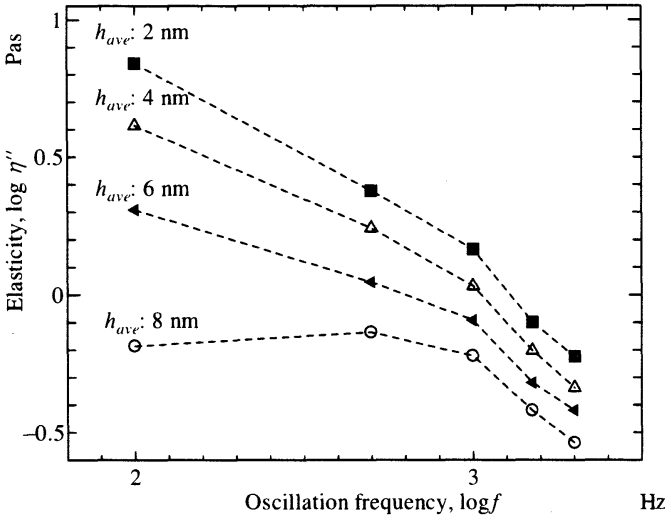

Fig. 16 Frequency dependence of the elasticity at representative gaps.

ノ閉じ込め状態に特有の shear thinning のメカニズムは 以下のようになる. まず，ナノ閉じ込めの効果により 分子運動の遅化した潤滑剂分子は, 隙間約 $15 \mathrm{~nm}$ 以下 において局所的な集合構造を形成する.これにより, せん断された潤滑剤分子は集団として運動するために 粘性係数が增大するだけでなく，固体的な性質である 弾性俰数を発現する. 加振周波数を增加させると, 潤 滑剂分子の集合構造が破塤されるために，弾性倸数は 減少し, さらには運動する分子集団の規模が微細化さ れるために, 粘性係数は減少する.すなわち shear thinning 挙動を示す.

本実験で得られた結果は, SFA で用いられる原子レ ベルで平滑な固体表面間に限らず，粗さを有する固体 表面間に閉じ込められた液体潤滑剂についても, shear thinning 挙動が観測されることを示したものである. 図9から図 13 に示した結果は, 供試ディスク上の同じ 位置を摺動した結果であるが，異なる位置を摺動した 際にも同様の測定結果を得ており, 本実験において, 摺動位置の違いによる粗さの突起分布のわずかな違い が，粘弾性特性の測定結果に与える影響は小さいこと を確認している.

ナノ閉じ込めによる液体の固体化の過程は, ガラス 転移と同様の過程であると解釈されている ${ }^{(11)(12)}$ ，すな わち，隙間を狭小化する効果は，温度を下げる効果と 同様であり，ナノ閉じ込めにより固体化した液体はガ ラス状態に似た分子状態であると考えられている.こ の考え方に従って, 本実験で得られた結果の解釈を試 みる. 隙間 $15 \mathrm{~nm}$ 以上では, 隙間の狭小化に伴って粘 性係数は增大するものの, 弾性は発現しない. また, この領域では加振周波数に対する粘性係数の依存性は みられない.これらの結果から,隙間 $15 \mathrm{~nm}$ 以上では,
潤滑剂は液体状態を維持しており，隙間の狭小化に伴 う粘性係数の增大は, 温度低下に伴う液体の粘度上昇 に相当すると考えられる. 隙間 $15 \mathrm{~nm}$ 以下では, 弾性 係数が增大し, shear thinning が顕在化する.これは, 隙間 $15 \mathrm{~nm}$ 以下において，潤滑剂がガラス状態に転移 したためと考えられる. 図10から図13において示し たように, 隙間の狭小化に伴う粘性係数の增加傾向は, 隙間 $15 \mathrm{~nm}$ 付近において屈曲点を示すことが明らかと なった.この屈曲点が現れる隙間は, 温度とのアナロ ジーに基づいて考えると，ガラス転移温度に相当する 隙間であると解釈することができる.

\section{5. 結諭}

分子サイズの微小隙間に閉じ込められた状態(ナ) 閉じ込め状態)の液体高分子に特有の shear thinning 挙 動のメカニズムを解明するために，ナノメートルオー ダの微小隙間に液体潤滑剂を介在させ，その粘弾性特 性の周波数依存性を測定した. 粘弾性特性の測定には, 著者らがこれまでの研究において独自に開発した，せ ん断力測定法(ファイバーウォブリング法)を用いた. 本法は $0.1 \mathrm{nN}$ オーダのせん断力検出, $0.1 \mathrm{~nm}$ オーダで の摺動隙間の設定, ならびに数 $\mathrm{Hz}$ から数 $\mathrm{kHz}$ に及ぶ 広帯域での動的粘弾性特性の測定が可能である. 本実 験では, 液体潤滑剂としてフッ素系潤滑剤(Fomblin Zdol)を, 潤滑剤を滴下する固体基板として DLC 保護 膜付きの磁気ディスク基板を用いた.

得られた結果を要約すると以下のとおりである.

(1) 測定した各加振周波数において, 粘性俰数は隙 間の狭小化に伴って增大し, 弾性係数は隙間 $15 \mathrm{~nm}$ 付 近から発現して, 隙間の狭小化とともに急增した. 500 $\mathrm{Hz}$ 以上の加振周波数において, 隙間の狭小化に伴う粘 性倸数の增加傾向は, $10 \mathrm{~nm} \sim 15 \mathrm{~nm}$ の隙間領域におい て屈曲点を示した. この屈曲点は, 次の(2)に述べるよ うに, 隙間が $15 \mathrm{~nm}$ を下回る領域から顕在化する shear thinning による粘性係数の減少が原因と考えられる.

（2）加振周波数に対する粘性俰数の依存性:は，隙間 が $15 \mathrm{~nm}$ を下回る領域から顕在化し，加振周波数の增 加とともに粘性係数が減少する shear thinning 挙動を示 した.

(3)粘性係数と同様に, 弾性係数は加振周波数の增加 に伴って減少し，その減少傾向は隙間の狭小化ととも に顕著となった. 弾性の発現は潤滑剂分子の集合構造 の形成に起因すると考えられるため, 弾性係数の減少 は, 加振周波数の增加によりその集合構造力゙破壊され たことが原因と考えられる. 
(4) shear thinning が顕在化する隙間と, 弾性が発現す る隙間がおおよそ 致した.このことから,ナノ閉じ 込めに特有の shear thinning は, 潤滑剂の集合構造の形 成およびその破㙥に相関があると考えられる. 集合構 造が破壊されることにより, せん断によって運動する 分子集団の規模が微細化され，粘性係数の減少を引き 起こしたと考えられる.

\section{付録 先端球と磁気ディスクとの接触域の見㮴もり}

本実験系においては, 摺動面は球面 (先端球) と平 面（磁気ディスク）により構成されている. したがっ て, 固体接触直後には, 理想的には点接触となるが, 実際には表面粗さが存在するために, ある有限の領域 が固体接触することとなる. 接触の様子を模式的に図 $\mathrm{A} 1$ に示す. 図 $\mathrm{A} 1$ 中, $d_{\text {contac } r}$ は接触域の代表的な長さ を示す．本実験においては球面と平面の接触であるの で, 接触域は円形と仮定し, その直径を接触域の代表 長さ $d_{\text {contact }}$ とする.

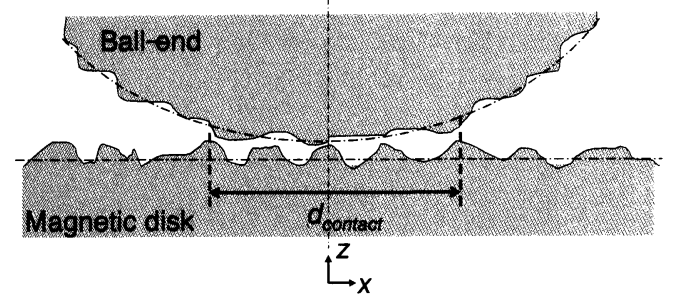

Fig. A1 Schematic view of the solid contact between the ball-end of the optical fiber probe and the magnetic disk.

図 A2 に示すように，先端球は曲率をもつために, その中心位置からの偏り $\Delta x$ によって, 隙間は $\Delta z$ 変化 する. この曲率による隙間の変化分 $\Delta z$ が, 表面粗さ が分布する隙間領域 $3 \mathrm{R}_{\mathrm{ms}}$ より小さい領域において, 確率的に固体接触が発生すると考えられる. したがっ て本実験系において, 接触域の代表長さ $d_{\text {contact }}$ は, 幾 何学的な関係から次式により求められる.

$$
d_{\text {contact }}=2 \Delta x=2 \sqrt{r^{2}-\left(r-3 \mathrm{R}_{\mathrm{rms}}\right)^{2}}
$$

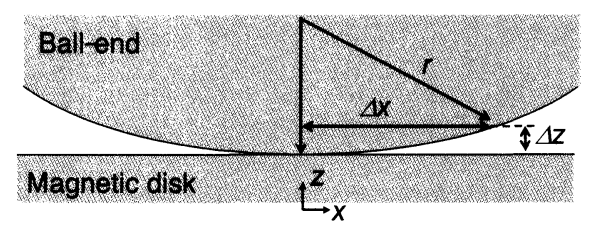

Fig. A2 Geometric configuration of the sliding surfaces of the ball-end and the magnetic disk.

\section{文献}

(1) Luengo, G., Schmitt, F. J., Hill, R., Israelachvili, J., Thin Film Rheology and Tribology of Confined Polymer Melts: Contrasts with Bulk Properties, Macromolecules, Vol. 30 (1997), pp. 2482-2494.

(2) Granick, S., Motions and Relaxations of Confined Liquids, Science, Vol. 253 (1991), pp. 1374-1379.

(3) Hu, H. W., Carson, G. A., Granick, S., Relaxation Time of Confined Liquids under Shear, Physical Review Letters, Vol. 66, No. 21 (1991), pp. 2758-2761.

(4) Yamada, S., General Shear-thinning Dynamics of Confined Fluids, Tribology Letters, Vol. 13, No. 3 (2002), pp. 167-171.

(5) Itoh, S., Fukuzawa, K., Zhang, H., Mitsuya, Y., Measurement of Nanorheological Properties of Molecularly Thin Confined Lubricant Film Using Fiber Wobbling Method, Transactions of the Japan Society of Mechanical Engineers, Series C, Vol. 70, No. 651 (2004), pp. 841-848.

(6) Itoh, S., Fukuzawa, K., Takahashi, K., Ando, T., Zhang, H., Mitsuya, Y., Optimization of Dynamic Shear Force Measurement for Fiber Wobbling Method, Microsystem Technologies, Vol. 11 (2005), pp. 894-900.

(7) Fukuzawa, K., Itoh, S., Ando, T., Takahashi, K., Zhang, H., Mitsuya, Y., Lateral Force Measurement Using a Probe Fiber as a Microlens, Journal of Applied Physics, Vol. 95, No. 9 (2004), pp. 5189-5191.

(8) Goldman, A. J., Cox, R. G., Brenner, H., Slow viscous motion of a sphere parallel to a plane wall - I Motion through a quiescent fluid, Chemical Engineering Science, Vol. 22 (1967), pp. 637-651.

(9) Hashimoto, H., Tribology, (2006), p. 94, Morikita.

(10) Ma, X., Spreading of Perfluoropolyalkylether Films on Amorphous Carbon Surfaces, Ph. D. Thesis, Carnegie Mellon University (1998).

(11) Demirel, A. L., Granick, S., Glasslike Transition of a Confined Simple Fluid, Physical Review Letters, Vol. 77, No. 11 (1996), pp. 2261-2264.

(12) Yamada, S., Nakamura, G., Hanada, Y., Amiya, T., Glasslike Transitions in Thin Polymer-melt films due to Thickness Constraint, Tribology Letters, Vol. 15, No. 2 (2003), pp. 83-89.

ここで, $r$ は先端球の曲率半径を表す. 第 $3 \cdot 1$ 節およ び第 $3 \cdot 2$ 節に示した值を式( $\mathrm{A} 1)$ に代入すると， $d_{\text {commact }}$ は $1.1 \mu \mathrm{m}$ と見積もられる. 